\title{
Genetic Analysis of Restriction Fragment Length Polymorphisms in Vitis
}

\author{
M.-C. Mauro, M. Strefeler, N. F. Weeden, and B. I. Reisch
}

The parents and progeny from two crosses (Cayuga White $\times$ Aurore and NY62.136.2 $\times$ Yates) were examined for the presence of DNA restriction fragment length polymorphisms (RFLPs). Seventeen independent DNA sequences were used in the analysis, 15 obtained from a grape PstI genomic library and two heterologous probes obtained from other laboratories. Most of the low copy cloned sequences hybridized to more than two restriction fragments, possibly reflecting the polyploid nature of the Vitis genome. Nine of the probes detected RFLPs between parents. Analysis of the progenies ( $F_{1}$ generation) revealed segregation for nine distinct polymorphisms generated by seven of the probes. Thus, a relatively high level of polymorphism among parents, as well as heterozygosity within each parent, was evident. Most RFLPs gave segregation ratios close to the $1: 1$ ratio predicted for a locus heterozygous in one parent. However four differences between parental phenotypes did not segregate in the progeny, and in three instances fragments present in both parents segregated in the progeny. These peculiar results may be explained by accounting for heterozygosity or homozygosity, respectively, for the DNA segment that generates the polymorphism. We conclude that RFLP studies can be performed on the first filial generation in woody perennials such as Vitis that have a relatively high level of heterozygosity in the genome.

Despite the fact that grape (Vitis spp.) is the oldest and most widely grown fruit crop in the world, few simply inherited characters have been identified in this genus. The crop has not been amenable to genetic analysis because of its relatively long generation time ( 2 to 5 years), its highly heterozygous nature and sensitivity to inbreeding depression, and a dearth of welldefined genetic markers. Genetic analyses of polymorphisms among 48 morphological traits have revealed that they are controlled by distinct loci (De Lattin 1957). However, the patterns of inheritance of many of these traits have not been well characterized, and the availability of clones with mutant characters is limited.

Genetic studies of many annual crop species have been augmented by the use of molecular markers such as allozymes or DNA restriction fragment length polymorphisms (RFLPs), and such markers will be important tools for plant breeders and geneticists. The widespread use of protein electrophoresis in woody crops has occurred only recently. A number of woody taxa, including several conifers (El-Kassaby et al. 1982; Harry 1986; Millar 1984), Eucalyptus (Moran and Bell 1983), and Ma- lus (Chevreau et al. 1985; Weeden and Lamb 1987) display relatively high levels of allozyme polymorphism, whereas others possess only a few disernable allozyme variants. RFLP studies can result in the placement of thousands of genetic markers in each species, many more than are possible with allozyme analysis. However, RFLP technology currently requires a considerable investment of time and money. Thus, it would be advantageous to be able to predict which woody taxa will be most conducive to this approach. Although a comprehensive study has yet to be made, there appears to be a positive correlation in herbaceous species between the level of allozyme variability present in a taxon and the ease with which RFLPs can be found in that taxon (Chao et al. 1989). This correlation may merely reflect an increase of both types of polymorphisms with genetic diversity. Nevertheless, because allozyme data are often available for species in which RFLP studies have yet to be performed, the correlation could prove to be very useful to investigators who are expanding RFLP technology to new taxa. The purposes of this study were to determine (1) if the relatively high level of allozyme 
polymorphism found in Vitis is accompanied by similarly abundant RFLPs and (2) if these RFLPs can be genetically analyzed and mapped using $F_{1}$ plants, an approach that has been successfully applied to isozyme loci in several woody perennials.

\section{Rlaterials and Aflerhoods}

The parents and unselected progeny of two crosses (81.316: Cayuga White $\times$ Aurore and 78.839: NY62.136.2 $\times$ Yates) were grown in the vineyards of the New York State Agricultural Experiment Station, Geneva, New York. The parents of these crosses were complex interspecific hybrids. The progeny of the first cross was previously surveyed for allozyme polymorphisms (Weeden et al. 1988).

We prepared high molecular weight DNA from young leaf tissue of the parents and progeny according to the method of Doyle and Doyle (1987). Approximately $7 \mu \mathrm{g}$ samples of this DNA were digested overnight using six restriction endonucleases (EcoRI, EcoRV, BamHI, HindIII Bgll, and $X b a I)$ according to the manufacturer's instructions. After separation by electrophoresis on $1 \%$ agarose gels, the DNA fragments were transferred to nylon membranes (GeneScreen Plus, Dupont, Wilmington, Delaware) by using a modification of the techniques of Southern (1975) in which the DNA was transferred to the membrane under alkaline conditions (Reed and Mann 1985).

We developed a partial genomic library from high molecular weight DNA isolated from young leaves of $V$. vinifera $\mathrm{cv}$. Cabernet Sauvignon. The DNA was digested with 0.12 units of the restriction endonuclease Pstl per $1.0 \mu \mathrm{g}$ DNA for $1 \mathrm{~h}$ at $37^{\circ} \mathrm{C}$. Approximately $40.0 \mu \mathrm{g}$ of this restricted DNA were ligated into $1.0 \mu \mathrm{g}$ of Pst I cut pBR322 (New England Biolabs, Beverly, Massachusetts). We incubated the restricted DNA and Pst I cut pBR322 for $4 \mathrm{~h}$ at room temperature in $200 \mathrm{mM}$ Tris ( $\mathrm{pH} \mathrm{6.0)}, 100 \mathrm{mM}$ dithiothreitol, $6 \mathrm{mM}$ ATP, and $1 \mu \mathrm{l}$ of T4 ligase. The ligated DNA was used to transform $E$. coli $\mathrm{DH} 5 \alpha$ competent cells according to the manufacturer's instructions (Life Technologies, Inc., Gaithersburg, Maryland). Transformed cells were stored at $-70^{\circ} \mathrm{C}$. We screened these clones for the presence of repetitive DNA inserts by extracting the recombinant plasmids via a rapid plasmid isolation procedure (Wilimzig 1985), blotting $10 \mu \mathrm{g}$ of plasmid DNA on a nylon membrane, and hybridizing them against ${ }^{32} \mathrm{P}$-labeled chloroplast DNA of Solanum hyporhodium and ${ }^{32} \mathrm{P}$-labeled total cellular DNA from $V$. vinifera. Plasmids containing inserts failing to hybridize to the cpDNA and displaying weak hybridization to the total cellular DNA were used as probes for the parental screening. We also used two heterologous clonesthe soybean actin gene (pSAc3, Shah et al. 1982) and a carrot genomic clone (A-56, provided by Dr. Phil Simon, USDA-ARS, Madison, Wisconsin)-to identify RFLPs.

Probe DNA was nick translated following the protocols of Maniatis et al. (1982) except that four units of DNase I/Polymerase I (Life Technologies, Inc., Gaithersburg, Maryland) were added to the 30$\mu \mathrm{l}$ reaction mixture instead of adding each enzyme separately. We incubated the nick translation mixture for $1-2 \mathrm{~h}$ at $14^{\circ} \mathrm{C}$, after which we separated the labeled probes from unincorporated nucleotides by spun column chromatography on a Sephadex G-50 $1 \mathrm{cc}$ column following the method of Maniatis et al. (1982). Before hybridization, the labeled probes were denatured in solution with $1 \mathrm{~N} \mathrm{NaOH}$ at room temperature for $10 \mathrm{~min}$.

We prehybridized the blots for 4-6 $\mathrm{h}$ at $65^{\circ} \mathrm{C}$ in approximately $10 \mathrm{ml}$ of buffer per $100 \mathrm{~cm}^{2}$ of blot. The hybridization buffer consisted of $750 \mathrm{mM} \mathrm{NaCl}, 125 \mathrm{mM}$ citric acid (trisodium salt, dihydrate), $2.5 \mathrm{mM}$ EDTA, $50 \mathrm{mM} \mathrm{NaPO}$, $5 \times$ Denhardt's, 0.4 $\mathrm{mg} / \mathrm{ml}$ calf thymus DNA, $5.0 \%$ dextran sulfate, and $0.6 \%$ SDS. Hybridization was carried out in the same buffer for $16-18 \mathrm{~h}$ at $65^{\circ} \mathrm{C}$ after adding denatured radiolabeled probe. After hybridization, the blots were washed two to three times in an excess of $2 \times \mathrm{SSC}+0.1 \% \mathrm{SDS}$ for $20 \mathrm{~min}$ at $65^{\circ} \mathrm{C}$. We performed more stringent washes $(1 \times \mathrm{SSC}$ and $0.1 \times \mathrm{SSC}$ ) on several occasions in attempts to simplify the pattern generated on autoradiograms. Autoradiography was carried out at $-70^{\circ} \mathrm{C}$. Segregation and linkage analyses were carried out using the LINKAGE-1 program of Suiter et al. (1983). Initially, we scored each segregating restriction fragment as being present or absent. Identification of allelic fragments occasionally permitted the heterozygous phenotype to be recognized. If both parents were heterozygous, the data were reanalyzed using an expected $3: 1$ or $1: 2: 1$ segregation ratio. The allozyme segregation data used in the linkage analyses were previously reported (Weeden et al. 1988).

\section{Resulis and Discussion}

High molecular weight DNA was obtained in good yield from young leaf tissue. Best results were obtained on rapidly expand- ing leaves one to two nodes from the shoot tip. Older leaves, especially those fully expanded, tended to give lower yields of DNA, and this DNA could not be cut to completion with the restriction endonucleases.

A small genomic library was generated from Cabernet Sauvignon. Approximately 200 recombinant plasmids were isolated; however, only 15 of these met the conditions of the screen and generated relatively few clear bands on autoradiograms. Of the 17 independent probes screened (15 grape genomic and two heterologous), nine displayed polymorphism between the parents of one or both crosses (Table 1). Most of the polymorphisms could be detected using EcoRI-cut DNA. Other enzymes also could have been used to score for RFLPs (for example, pGG224 showed polymorphism for HindIII and $\mathrm{XbaI}$ ); however, the number of blots required for the analysis was minimized by using EcoRI polymorphisms when they were available. Fifteen of the 17 probes generated autoradiograms with more than two fragments hybridizing to the probe DNA. In those cases tested (pGG65, pGG224, pGG319), the observed pattern was not simplified significantly when higher stringency washes were performed.

Seven of the nine probes displaying interparent polymorphism also showed segregation in the progenies (Table 2). Five of these probes (pGG75, pGG243, pGG254, pGG276, and A56) visualized just one polymorphic fragment, segregating as either present or absent in the phenotype. The segregation of each of these approximated the expected 1:1 ratio for a single heterozygous locus (Table 2), although for pGG75 the deviation from 1:1 was significant at $P$ $=.05$.

The probe pGG224 revealed two band differences between each pair of parents, but only one of these polymorphisms segregated in each progeny (Table 2). The two segregating polymorphisms gave a 1:1 phenotypic ratio in the progenies, indicating that the parent possessing the restriction fragment was heterozygous for the restriction site(s) generating that fragment. The two nonsegregating polymorphisms were uniformly present in the respective progeny, suggesting that the parent with the restriction fragment was homozygous for the appropriate restriction sites. The two probes, pGG238 and pSAc3, also gave results similar to the nonsegregating polymorphisms of pGG224. Band intensity, as measured visually, was not particularly helpful for discriminating between homozygous and heterozygous 
Table 1. Clones evaluated, number of restriction fragments resolved by each clone, and endonucleases most practical for resolving polymorphisms

\begin{tabular}{lll} 
Clone $^{\circ}$ & $\begin{array}{l}\text { No. of } \\
\text { fragments }\end{array}$ & $\begin{array}{l}\text { Endo- } \\
\text { nuclease } \\
\text { used }\end{array}$ \\
\hline pGG75 & $4-5$ & EcoRI \\
pGG224 & $6-7$ & EcoRI \\
pGG238 & $5-6$ & EcoRI \\
pGG243 & $3-4$ & EcoRI \\
pGG254 & $3-4$ & HindIII \\
pGG276 & $3-4$ & EcoRI \\
pGG319 & $5-6$ & EcoRI \\
pSAc3 & $5-8$ & EcoRI \\
A-56 & $2-3$ & BamHI \\
\hline
\end{tabular}

aGG26, pGG57, pGG65, pGG73, pGG110, pGG111, pGG219, and pGG269 generated autoradiograms with 1-7 bands, all of which were invariant among the parents and the progenies examined.
Table 2. Single-locus segregations and chi square analyses for RFLPs in segregating grapevine $F_{1}$ populations

\begin{tabular}{|c|c|c|c|c|c|}
\hline \multirow[b]{2}{*}{ RFLP locus } & \multirow{2}{*}{$\begin{array}{l}\text { Heterozygous parent } \\
\text { or progeny }\end{array}$} & \multicolumn{2}{|c|}{ Ratio in progeny } & \multirow[b]{2}{*}{$\chi^{2}$} & \multirow[b]{2}{*}{$P$} \\
\hline & & Present & Absent & & \\
\hline pGG75 & Yates & 20 & 9 & 4.17 & .04 \\
\hline pGG224 & Aurore & 24 & 23 & 0.02 & .88 \\
\hline pGG224 & NY62.136.2 & 16 & 11 & 0.92 & .33 \\
\hline pGG243 & Yates & 14 & 12 & 0.15 & .69 \\
\hline pGG254 & NY62.136.2 & 15 & 12 & 0.33 & .56 \\
\hline pGG276 & Aurore & 7 & 8 & 0.07 & .80 \\
\hline pGG319 (13 kb) & 81.316 & 43 & 10 & $1.06^{a}$ & 31 \\
\hline pGG319 (13 kb) & 78.839 & 24 & 10 & $0.35^{\circ}$ & .55 \\
\hline pGG319 (10 kb) & 81.316 & 28 & 25 & 0.17 & .68 \\
\hline pGG319 (10 kb) & 78.839 & 21 & 13 & 1.88 & .18 \\
\hline pGG319 $(6 \mathrm{~kb})$ & 81.316 & 36 & 17 & $1.42^{a}$ & .24 \\
\hline pGG319 (6 kb) & 78.839 & 28 & 5 & $1.92^{a}$ & .18 \\
\hline A56 & NY62.136.2 & 17 & 14 & 0.29 & .59 \\
\hline
\end{tabular}

${ }^{a}$ Expected ratio 3:1.

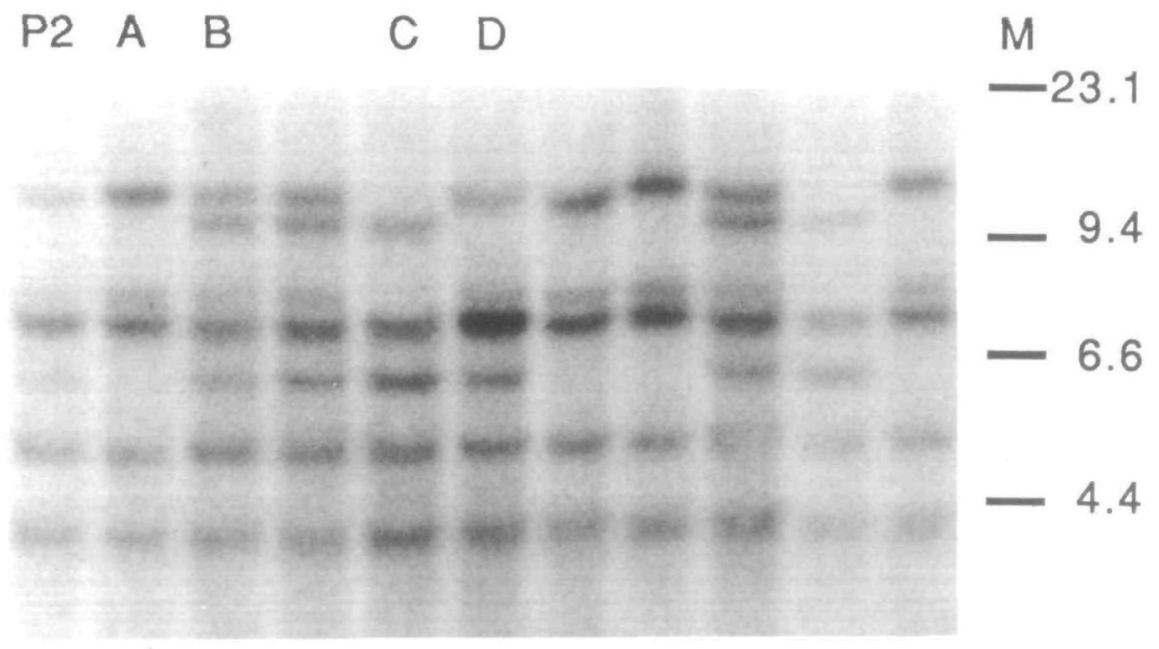

$\begin{array}{lll}M & \text { P1 } & \text { P2 }\end{array}$

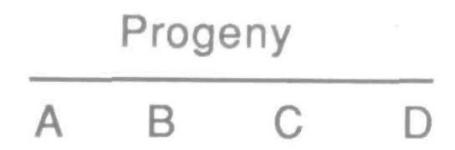

$23.1-$

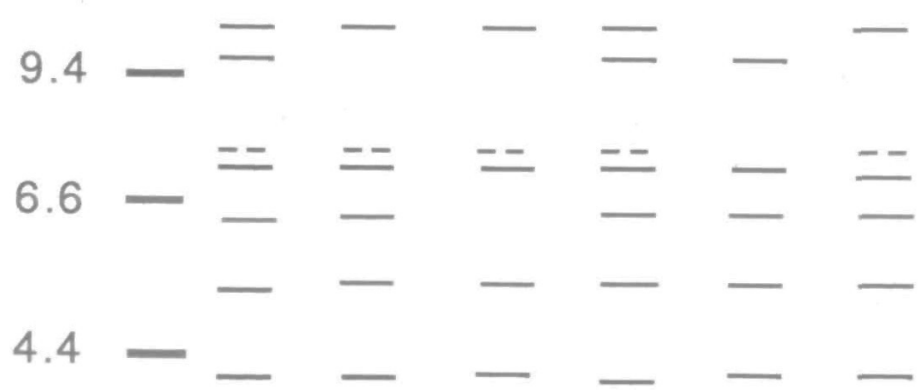

Figure 1. EcoRl restriction length phenotypes generated by pGG319. The upper portion of the figure shows the Aurore phenotype in the left lane and individual progeny from the Cayuga White $x$ Aurore cross in the remaining 10 lanes. The lower section diagrams all phenotypes. Designations are $\mathrm{P1}=$ Cayuga White or NY62.136.2; $\mathrm{P} 2=$ Aurore or Yates; A, B, C, and D = four phenotypes observed in progenies; $M=$ HindlII cut lambda DNA. genotypes, and we were unable to predict from the band intensity in the parental pattern whether that band would segregate in the progeny.

Plasmid pGG319 generated a relatively complicated set of phenotypes in which four restriction fragments segregated (Figure 1). The same two parental phenotypes were present in both crosses, those for Cayuga White and NY62.136.2 being identical, as were those for Aurore and Yates. Except for minor differences in the intensity of certain bands, the only difference between the two phenotypes was that $\mathrm{Ca}$ yuga White and NY62.136.2 possessed a 10-kb fragment, whereas the other phenotype lacked such a band (Figure 1). All four fragments displayed segregation in both progenies, yet only four phenotypes were observed. We interpreted these results to indicate that each parent must be heterozygous and that at least three alleles must be present in each cross. According to our model, Cayuga White and NY62.136.2 possess one "allele" (DNA sequence) that generates a $13-\mathrm{kb}$ and a faint $7.5-\mathrm{kb}$ fragment and a second allele that generates 10- and 6-kb fragments. In contrast, Aurore and Yates possess an allele that generates only a 6-kb fragment as well as an allele that produces the $13-\mathrm{kb}$ and faint $7.5-\mathrm{kb}$ fragments. The model predicts that the 13$\mathrm{kb}, 7.5-\mathrm{kb}$, and $6-\mathrm{kb}$ fragments should each show 3:1 segregation ratios, and the $10-\mathrm{kb}$ fragment should segregate in a 1:1 ratio. In addition, the four phenotypes distinguishable in the progenies should segregate in a 1:1:1:1 ratio. All the predictions of the model were fulfilled (Tables 2 and $3)$.

Joint segregation analysis of the RFLPs and the isozyme loci described previously 
Table 3. Segregation analysis of PGG319 phenotypes

\begin{tabular}{|c|c|c|c|c|c|c|c|c|}
\hline \multirow[b]{2}{*}{ Cross } & \multirow[b]{2}{*}{$N$} & \multicolumn{4}{|c|}{ No. with designated phenotype } & \multirow{2}{*}{$\begin{array}{l}\text { Expected } \\
\text { ratio }\end{array}$} & \multirow[b]{2}{*}{$\chi^{2}$} & \multirow[b]{2}{*}{$P$} \\
\hline & & $\overline{\mathrm{A}}$ & B & $\mathrm{C}$ & D & & & \\
\hline $\begin{array}{l}81.316 \\
78.839\end{array}$ & $\begin{array}{l}53 \\
34\end{array}$ & $\begin{array}{r}17 \\
5\end{array}$ & $\begin{array}{l}18 \\
11\end{array}$ & $\begin{array}{l}8 \\
8\end{array}$ & $\begin{array}{l}10 \\
10\end{array}$ & $\begin{array}{l}1: 1: 1: 1 \\
1: 1: 1: 1\end{array}$ & $\begin{array}{l}5.64 \\
2.47\end{array}$ & $\begin{array}{l}.1-.2 \\
.3-.5\end{array}$ \\
\hline
\end{tabular}

- Phenotypic designations are those as given in Figure 1 , which represent the four patterns observed on autoradiograms.

(Weeden et al. 1988) failed to identify any new linkage groups for grape. This failure to find additional linkages is not particularly surprising when one considers that, in this type of analysis, the segregating loci must be heterozygous in the same parent for linkage to be observed. The nine distinct (i.e., assorting independently or in different $F_{1}$ progenies) segregating phenotypes listed in Table 2 were distributed among four parents. Thus the number of actual comparisons available for linkage analysis is much lower than the total number of loci investigated. However, this study clearly demonstrates that RFLPs are prevalent in Vitis. Nine segregating loci could be scored after screening 17 low copy nuclear sequences.

The relatively high number of fragments hybridizing to most probes may indicate that most low copy DNA fragments are present as two or more closely related DNA sequences in the grape genome. Olmo
(1976) indicated that grape probably is of polyploid origin. The multiplicity of closely related sequences in the genome may reflect its polyploid nature. Continued analysis of the Cayuga White $\times$ Aurore and other suitable progenies should permit the development of a complete linkage map for grape, as well as a detailed genetic characterization of this species.

\section{References}

Chao S, Sharp PJ, Worland AJ, Warham EJ, Koebner RMD, and Gale MD, 1989. RFLP-based genetic maps of wheat homoeologous group 7 chromosomes. Theor Appl Genet 78:495-504.

Chevreau E, Lespinasse Y, and Gallet M, 1985. Inheritance of pollen enzymes and polyploid origin of apple (Malus $\times$ domestica Borkh.). Theor Appl Genet 74:261268.

De Lattin G, 1957. Zur Genetik der Reben: Bisherige Ergebnisse der Faktorenanalyse bei der Gattung Vitis. Vitis $1: 1-8$.

Doyle JJ and Doyle JL, 1987. A rapid DNA isolation procedure for small quantities of fresh leaf tissue. Phytochem Bull 19:11-15.
El-Kassaby YA, Yeh FC, and Sziklai O, 1982. Inheritance of allozyme variants in coastal Douglas fir (Pseudotsuga menziesii var. menziesii). Can J Genet Cytol 24:325335.

Harry DE, 1986. Inheritance and linkage of isozyme variants in incense-cedar. J Hered 77:261-266.

Maniatis T, Fritsch EF, and Sambrook J, 1982. Molecular cloning: a laboratory manual. Cold Spring Harbor, New York: Cold Spring Harbor Laboratory Press.

Millar $\mathrm{Cl}$, 1984. Inheritance of allozyme variants in bishop pine (Pinus muricata D. Don). Biochem Genet 23:933-945.

Moran GF and Bell JC, 1983. Eucalyptus. In: Isozymes in plant genetics and breeding, Part B (Tanksley SD and Orton TJ, eds). Amsterdam: Elsevier; 423-442.

Olmo HP, 1976. Grapes. In: Evolution of crop plants (Simmonds NW, ed). London: Longman; 294-298.

Reed KC and Mann DA, 1985. Rapid transfer of DNA from agarose gels to nylon membranes. Nucleic Acids Res 13:7207-7221.

Shah DM, Hightower RC, and Meagher RB, 1982. Complete nucleotide sequence of a soybean actin gene. Proc Natl Acad Sci USA 79:1022-1026.

Southern EM, 1975. Detection of specific sequences among DNA fragments separated by gel electrophoresis. J Mol Biol 98:503-517.

Suiter KA, Wendel JF, and Case JS, 1983. LINKAGE-1: a PASCAL computer program for the detection of genetic linkage. J Hered 74:203-204.

Weeden NF and Lamb RC, 1987. Genetics and linkage analysis of 19 isozyme loci in apple. J Am Soc Hort Sci 112:865-872.

Weeden NF, Reisch BI, and Martens MH, 1988. Genetic analysis of isozyme polymorphism in grape. J Am Soc Hort Sci 113:765-769.

Wilimzig M, 1985. LiCl-boiling method for plasmid minipreps. Trends Genet 1:158. 